\title{
PENERAPAN METODE WEIGHTED AGGREGATED SUM PRODUCT ASSESMENT DALAM MENENTUKAN BERAS TERBAIK UNTUK PEMBUATAN KUE SERABI
}

\author{
Tundo*1, Doni Kurniawan $^{2}$ \\ ${ }^{1}$ Informatika UIN Sunan Kalijaga Yogyakarta, ${ }^{2}$ Informatika Universitas Teknologi Yogyakarta \\ Email: ${ }^{1}$ asna8mujahid@gmail.com, ${ }^{2}$ dony.kurniawan53@gmail.com \\ *Penulis Korespondensi
}

(Naskah masuk: 07 Agustus 2019, diterima untuk diterbitkan:23 Oktober 2019)

\begin{abstract}
Abstrak
Penelitian ini bertujuan untuk membantu pedagang kue serabi di Kota Tegal dalam menentukan beras terbaik yang akan digunakan sebagai bahan utama dalam pembuatan kue serabi, karena sering terjadi keluhan dari konsumen bahwa beras yang dijadikan sebagai bahan pembuatan kue serabi dari segi aroma kurang mengeluarkan aroma kue serabi dan dari segi kekuatan cepat hancur. Berdasarkan permasalahan tersebut, dicari suatu solusi dengan menggunakan metode Weighted Aggregated Sum Product Assesment (WASPAS) serta dibantu oleh pakar dalam menentukan kriteria yang tepat berkaitan penentuan beras terbaik dalam pembuatan kue serabi, ditemukan kriteria yang tepat berdasarkan permasalahan, berupa kriteria kekuatan, tekstur, aroma dan harga. Semua kriteria tersebut, kemudian diproses dengan menggunakan metode WASPAS, setelah diproses, diperoleh hasil beras terbaik yang tepat untuk digunakan sebagai bahan pembuatan kue serabi adalah beras pelita dengan hasil 7,12 dengan menduduki peringkat pertama. Membuktikan hasil dari metode WASPAS, maka dilakukan kuisioner secara langsung kepada pedagang kue serabi, khususnya yang ada di Tegal menghasilkan prosentase $80 \%$ dari 100 , yang mengatakan bahwa beras pelita adalah beras yang layak untuk dijadikan sebagai bahan pembuatan kue serabi karena kue serabi yang dihasilkan lebih wangi dan segar dan harganya pun relatif murah.
\end{abstract}

Kata kunci: Weighted Aggregated Sum Product Assesment (WASPAS), Beras terbaik, Kue serabi.

\section{APPLICATION of THE WASPAS METHOD IN DETERMINING THE BEST RICE FOR MAKING SERABI CAKE}

\begin{abstract}
This study aims to help pancake traders in the city of Tegal in determining the best rice that will be used as the main ingredient in making pancake cakes, because complaints often occur from consumers that rice is used as a material for making pancake cakes in terms of the scent lacking the aroma of pancake cakes and in terms of strength is quickly destroyed. Based on these problems, a solution is sought using the Weighted Aggregated Sum Product Assessment (WASPAS) method and assisted by experts in determining the right criteria related to determining the best rice in making pancakes, found the right criteria based on the problem, in the form of strength, texture, aroma and price. All of these criteria are then processed using the WASPAS method, after processing, the best rice yields that are suitable for use in making pancake cakes are pelita rice with a yield of 7.12 with the first rank. Proving the results of the WASPAS method, a questionnaire was conducted directly to pancake cake traders, especially those in Tegal, producing a percentage of $80 \%$ of 100, which said that pelita rice was rice worthy of being used as material for making pancakes because of cakes the pancake produced is more fragrant and fresher and the price is relatively cheap.
\end{abstract}

Keywords: Weighted Weighted Aggregate Product Assessment (WASPAS), the best rice, serabi cake.

\section{PENDAHULUAN}

Beras merupakan satu dari alternatif bahan dasar dari kue serabi yang mengandung karbohidrat, mineral, lemak, protein, dan vitamin yang digunakan sebagai bahan utama dalam pembuatan kue serabi. Pada saat ini daya konsumtif masyarakat terhadap kue serabi semakin tinggi, khususnya di kota Tegal. Permintaan kue serabi juga meningkat. Oleh sebab itu, perusahaan produksi kue serabi perlu 
meningkatkan kualitas produk kue serabinya khususnya dalam pemilihan bahan baku beras untuk pembuatan kue serabi. Pada pengambilan keputusan yang banyak melibatkan faktor, maka perlu digunakan suatu metode tertentu. Salah satu metode yang digunakan adalah metode WASPAS. Metode Weighted Aggregated Sum Product Assesment (WASPAS), ini adalah sebuah rancangan untuk mengambil suatu keputusan dengan efektif atas persoalan yang kompleks dengan menyederhanakan dan mempercepat proses pengambil keputusan dengan memecahkan persoalan tersebut kedalam bagian-bagiannya, menata bagian atau variabel ini dalam suatu susunan hierarki (Chakraborty and Zavadskas, 2014), memberi nilai numerik pada pertimbangan subjektif tentang pentingnya tiap variabel dan mensinstesis berbagai pertimbangan pertimbangan ini untuk menetapkan variabel dan mensintesis mana yang memiliki prioritas paling tinggi dan bertindak untuk mempengaruhi hasil pada situasi tersebut. Metode WASPAS ini membantu memecahkan persoalan yang kompleks dengan menstruktur.

Pada sistem pendukung keputusan menurut (Stanujkić and Karabašević, 2019), terdapat banyak metode yang dapat digunakan untuk menghasilkan solusi dalam mendapatkan alternatif terbaik, diantaranya sistem pendukung keputusan metode AHP, SAW, WP, SMART, dan MOORA. Dalam pengembangannya juga dapat menggunakan fuzzy untuk menghasilkan keputusan yang lebih efektif. Pengembangan teknologi informasi dan komputer khususnya pada bidang sistem pendukung keputusan juga merambah pada bidang manajemen, pemasaran dan bisnis, hal ini dapat dilihat pada kebutuhan manajemen untuk menghasilkan keputusan yang lebih efektif dalam pengendalian terhadap strategi pemasaran maupun keberlanjutan bisnis yang besar, seperti manajemen penentuan bahan baku terbaik akan tetapi, dengan harga yang relatif ringan.

Berikut beberapa penelitian yang serupa yang peneliti ambil sebagai bahan dalam pembuatan penelitian ini. Pertama menurut Penelitian oleh (Gulo, 2020), dengan objek pemilihan kantor pos terbaik. Data Alternatif yang ada yaitu, kantor pos di area khusus Sumatra Utara, dalam penelitian memberikan contoh A1, A2, A3, A4, dan A5 yang sekiranya tepat untuk dipilih menjadi kantor pos terbaik dengan dipengaruhi oleh 4 kriteria. Dari hasil menggunakan metode WASPAS, diperoleh bahwa kantor pos A1 mempunyai nilai yang paling tinggi yaitu, 2.124 maka kantor pos A1 adalah alternatif yang tepat untuk dikategorikan sebagai kantor pos terbaik. Selanjutnya penelitian oleh (Amalia, Syamsuar and Atika, 2019), dengan objek penentuan penerima beasiswa penelusuran minat dan kemampuan. Data Alternatif yang ada adalah calon mahasiswa STMIK Bina Nusantara Jaya Lubuklinggau, dalam penelitian memberikan contoh V1, V2, V3, V4, sampai dengan V10 yang sekiranya tepat untuk menerima beasiswa penelusuran minat dan kemampuan dengan dipengaruhi oleh kriteria pekerjaan orang tua, penghasilan, tanggungan, prestasi akademik dan non, serta status tempat tinggal. Dari hasil menggunakan metode WASPAS, diperoleh bahwa calon mahasiswa V8 mempunyai nilai yang paling tinggi yaitu, 0.960 maka calon mahasiswa V8 adalah alternatif yang layak untuk menerima beasiswa penelusuran minat dan kemampuan. Penelitian oleh (Chandra and Hansun, 2019), dengan objek rekomendasi pemilihan lapto, dengan cara melakukan survei sederhana menggunakan angket. Berdasarkan hasil survei, sebagian besar responden mengaku pernah mengalami kesulitan dalam memilih laptop yang sesuai dengan keinginan responden. Berdasarkan permasalahan tersebut, dibuat suatu metode WASPAS. Hasil perhitungan Cronbach's Alpha terhadap hasil uji kepuasan menghasilkan nilai sebesar 0.83 yang menunjukkan bahwa hasil uji kepuasan pengguna tergolong reliable.

Penelitian oleh (Nisa, 2020), dengan objek penentuan prioritas dalam peningkatan kualitas mata pelajaran. Data Alternatif yang ada yaitu, nama mata pelajaran, dalam penelitian memberikan contoh mata pelajaran Bahasa Arab, Bahasa Indonesia, PKN, Matematika, IPA, dan IPS, yang sekiranya tepat untuk diprioritaskan dalam peningkatan nilai dengan dipengaruhi oleh kriteria KKM, keaktifan, merangkum, dan kemampuan. Dari hasil menggunakan metode WASPAS, diperoleh bahwa mata pelajaran yang perlu diprioritaskan untuk peningkatan nilai yaitu Matematika dan Bahasa Arab karena nilai yang diperoleh di bawah KKM. Penelitian oleh (Gusman, Linostu and Sumaryanti, 2020), dengan objek penentuan ikan teri asin kering berkualitas terbaik. Data Alternatif yang ada yaitu, para pemasok ikan kering, dalam penelitian memberikan contoh Buk Rina Nose, Mas Budi Anduk, dan Pak Yosef yang sekiranya tepat untuk dipilih menjadi pemasok ikan teri asin kering terbaik dengan dipengaruhi oleh kriteria ukuran ikan, warna ikan, aroma ikan, tekstur ikan, dan daya tahan simpan ikan. Dari hasil menggunakan metode WASPAS, diperoleh bahwa pemasok ikan teri asin kering terbaik adalah Pak Yosef dengan nilai yang paling tinggi yaitu, 6.765, dan yang terakhir penelitian oleh (Handayani and Marpaung, 2018), dengan objek pemilihan kepala laboratorium. Data Alternatif yang ada yaitu, laboratorium setempat, dalam penelitian memberikan contoh A1, A2, A3, A4, sampai dengan A10 yang sekiranya tepat untuk dijadikan sebagai kepala laboratorium dengan dipengaruhi oleh kriteria kedisiplinan, masa kerja, kompetensi keahlian, kompetensi kepribadian, dan kompetensi sosial. Dari hasil menggunakan metode WASPAS, diperoleh bahwa kepala laboratorium A4 mempunyai nilai yang paling tinggi yaitu, 0.92 maka A4 adalah alternatif yang layak untuk dijadikan sebagai kepala laboratorium. 
Berdasarkan hal-hal yang telah dijelaskan di atas, pemodelan penelitian ini dilakukan dengan tujuan untuk membantu pedagang kue serabi di Tegal dalam menentukan beras yang terbaik untuk dijadikan sebagai bahan pembuatan kue serabi, dengan bantuan pakar ahli.

\section{METODE PENELITIAN}

\subsection{Analisis Kasus}

Analisis dilakukan secara wawancara langsung kepada para pedagang kue serabi di kota Tegal. Permasalahan yang terjadi adalah hampir sebagian besar pedagang kue serabi, khususnya di kota Tegal masih kurang mengetahui pentingnya kualitas kue serabi yang dijual, karena dalam melakukan pembuatan kue serabi hanya mementingkan harga beras yang paling murah tanpa mengetahui kualitas beras tersebut layak atau tidak untuk dijadikan sebagai bahan pembuatan kue serabi. Berdasarkan permasalahan itu, peneliti ingin mencoba membuat penelitian dalam menentukan beras terbaik yang digunakan untuk pembuatan kue serabi dengan menggunakan metode Weighted Aggregated Sum Product Assesment (WASPAS), dengan tujuan mengurangi ketidaktahuan pedagang kue serabi dalam menentukan beras terbaik serta meningkatkan mutu kualitas beras yang digunakan dalam pembuatan kue serabi.

\subsection{Pakar}

Pakar disini berguna dalam menentukan kriteria yang umum digunakan dalam membuat kue serabi dari bahan beras yang digunakan, serta menentukan himpunan dari setiap kriteria, beserta nilainya, dengan mengacu kepada permasalahan yang bersangkutan, setelah itu disepakati bahwa kriteria yang digunakan untuk menentukan beras terbaik untuk pembuatan kue serabi, terdiri dari kekuatan, tekstur, aroma, dan harga beras.

\subsection{Metode WASPAS}

Menurut (Turskis et al., 2019), Metode Weight Aggregated Sum Product Assesment (WASPAS) adalah mencari prioritas pilihan lokasi yang paling sesuai dengan menggunakan pembobotan. Penggunaan metode ini merupakan kombinasi dari dua sumber yang dikenal dengan WMM dan model produk berat (WPM) pada awalnya memerlukan normalisasi linier dari elemen hasil. Menggunakan metode WASPAS, kriteria kombinasi optimum dicari berdasarkan dua kriteria optimum. Kriteria pertama yang optimal, kriteria rata-rata keberhasilan sama dengan metode WSM. Pendekatan ini merupakan yang populer dan digunakan MCDM untuk pengambilan keputusan. Berikut merupakan langkah-langkah kerja dari metode Weighted Aggregated Sum Product Assesment (WASPAS), yaitu: a. Mempersiapkan sebuah Matriks

$$
\mathrm{X}=\begin{array}{ccc}
X 11 & X 12 & X 1 n \\
X 21 & X 22 & X 2 n \\
\ldots & \ldots & \ldots \\
X m 1 & X m 2 & X m 3
\end{array}
$$

Dimana $m$ adalah jumlah alternatif kandidat, $\mathrm{n}$ adalah jumlah kriteria evaluasi dan xij adalah kinerja alternatif sehubungan dengan kriteria j (Ickhsan et al., 2018).

b. Menormalisasikan nilai $R_{i j}$ dengan rumus sebai berikut :

Kriteria Keuntungan (Benefit) adalah atribut keuntungan, dimana jika nilai terbesar adalah terbaik (Barus et al., 2018).

$$
\mathrm{X}_{\mathrm{ij}}=\frac{\mathrm{Xij}}{\operatorname{Max} \mathrm{Xij}}
$$

Kriteria Biaya (Cost)

adalah atribut cost adalah atribut biaya, dimana jika nilai terkecil adalah terbaik (Marbun et al., 2018).

$$
\mathrm{X}_{\mathrm{ij}}=\frac{\operatorname{Min} \mathrm{Xij}}{\mathrm{Xij}}
$$

c. Menghitung nilai Alternatif (Qi) dengan menggunakan rumus sebagai berikut :

$$
\mathrm{Qi}=0,5 \sum_{j=1}^{n} \mathrm{Xij} W j+0,5 \prod_{j=1}^{n}(\mathrm{Xij})^{\mathrm{wj}}
$$

Nilai Qi yang terbaik merupakan nilai yang tertinggi (Andini et al., 2018).

\subsection{Akurasi}

Akurasi yang digunakan dengan menggunakan kuisioner secara langsung kepada pedagang kue serabi di kota Tegal, dengan menanyakan perbedaan yang terjadi setelah mengetahui bahwa dalam membuat kue serabi memiliki kualitas beras tersendiri serta dipraktekan secara langsung terhadap hasil beras yang direkomendasikan.

\section{HASIL DAN PEMBAHASAN}

Kriteria yang direkomendasikan pakar berdasarkan permasalahan yang ada dapat dilihat pada Tabel 1. Kriteria berikut ini.

Tabel 1. Kriteria

\begin{tabular}{llll}
\hline Kriteria & Keterangan & Atribut & Bobot \\
\hline C1 & Kekuatan & Benefit & 5 \\
C2 & Tekstur & Benefit & 4 \\
C3 & Aroma & Benefit & 3 \\
C4 & Harga & Cost & 2 \\
\hline
\end{tabular}


776 Jurnal Teknologi Informasi dan Ilmu Komputer (JTIIK), Vol. 7, No. 4, Agustus 2020, hlm. 773-778

Kemudian dari Tabel 1. Kriteria memiliki himpunan dan nilai, kecuali harga karena harga berisi angka yang sudah jelas nilainya (Tundo and Kurniawan, 2019). Berikut tabel dari himpunan kriteria:

\begin{tabular}{llll} 
& \multicolumn{3}{c}{ Tabel 2. Himpunan dari kriteria } \\
\hline Kriteria & Keterangan & Himpunan & Nilai \\
\hline C1 & Kekuatan & Kuat & 5 \\
& & Mudah patah & 3 \\
C2 & \multirow{2}{*}{ Tekstur } & Bergurat & 5 \\
& & Agak & 4 \\
& & bergurat & \\
& & Tidak & 3 \\
& & bergurat & \\
C3 & Natural & 5 \\
& Aroma & Apek & 3 \\
\hline
\end{tabular}

Selanjutnya diberikan beberapa alternatif beras yang ada, kemudian akan dipilih yang terbaik dari beberapa 15 alternatif beras yang ada. Tampak seperti pada Tabel 3. Alternatif berikut ini.

\begin{tabular}{cl}
\multicolumn{2}{c}{ Tabel 3. Alternatif } \\
\hline Alternatif & Keterangan \\
\hline A1 & Ramos \\
A2 & Pandan Wangi \\
A3 & Rojo Lele \\
A4 & IR42 \\
A5 & Beras Lembang \\
A6 & Metik Wangi \\
A7 & C4 \\
A8 & Beras Merah \\
A9 & Beras Hitam \\
A10 & Beureum Sengit \\
A11 & Beras Pelita \\
A12 & Beras Bulog \\
A13 & Beras Mutiara \\
A14 & Beras Jasmine \\
A15 & Beras Emas \\
\hline
\end{tabular}

Berdasarkan Tabel 3. Alternatif di atas setiap nama beras memiliki bentuk dan ciri masingmasing yang tampak pada Tabel 4.

Langkah selanjutnya, rubah ke dalam bentuk pembobotan sesuai dengan nilai yang terdapat di Tabel 2. Himpunan dari kriteria, kecuali harga karena kriteria harga sudah dalam bentuk numerik, sehingga datanya berubah seperti pada Tabel 5 . Pembobotan.

\begin{tabular}{|c|c|c|c|c|}
\hline Alternatif & C1 & C2 & C3 & C4 \\
\hline A1 & Kuat & $\begin{array}{l}\text { Tidak } \\
\text { Bergurat }\end{array}$ & Natural & 8500 \\
\hline A2 & Kuat & $\begin{array}{l}\text { Tidak } \\
\text { Bergurat }\end{array}$ & Natural & 8000 \\
\hline A3 & $\begin{array}{l}\text { Mudah } \\
\text { Patah }\end{array}$ & Bergurat & Natural & 8500 \\
\hline A4 & Kuat & $\begin{array}{l}\text { Agak } \\
\text { Bergurat }\end{array}$ & Apek & 8000 \\
\hline A5 & $\begin{array}{l}\text { Mudah } \\
\text { Patah }\end{array}$ & Bergurat & Natural & 8500 \\
\hline
\end{tabular}

\begin{tabular}{|c|c|c|c|c|}
\hline Alternatif & C1 & $\mathrm{C2}$ & C3 & $\mathrm{C4}$ \\
\hline A6 & Kuat & Bergurat & Natural & 8500 \\
\hline A7 & Kuat & $\begin{array}{l}\text { Agak } \\
\text { Bergurat }\end{array}$ & Apek & 7000 \\
\hline A8 & Kuat & Bergurat & Natural & 9000 \\
\hline A9 & Kuat & Bergurat & Natural & $\begin{array}{l}1000 \\
0\end{array}$ \\
\hline A10 & $\begin{array}{l}\text { Mudah } \\
\text { Patah }\end{array}$ & $\begin{array}{l}\text { Agak } \\
\text { Bergurat }\end{array}$ & Apek & 8500 \\
\hline A11 & Kuat & Bergurat & Natural & 7000 \\
\hline A12 & $\begin{array}{l}\text { Mudah } \\
\text { Patah }\end{array}$ & $\begin{array}{l}\text { Tidak } \\
\text { Bergurat }\end{array}$ & Apek & 6000 \\
\hline A13 & $\begin{array}{l}\text { Mudah } \\
\text { Patah }\end{array}$ & $\begin{array}{l}\text { Tidak } \\
\text { Bergurat }\end{array}$ & Apek & 7500 \\
\hline A14 & $\begin{array}{l}\text { Mudah } \\
\text { Patah }\end{array}$ & Bergurat & Apek & 8000 \\
\hline A15 & Kuat & Bergurat & Natural & 9500 \\
\hline
\end{tabular}

\begin{tabular}{lllll}
\multicolumn{5}{c}{ Tabel 5. Pembobotan } \\
\hline Alternatif & C1 & C2 & C3 & C4 \\
\hline A1 & 5 & 3 & 5 & 8500 \\
A2 & 5 & 3 & 5 & 8000 \\
A3 & 3 & 5 & 5 & 8500 \\
A4 & 5 & 4 & 3 & 8000 \\
A5 & 3 & 5 & 5 & 8500 \\
A6 & 5 & 5 & 5 & 8500 \\
A7 & 5 & 4 & 3 & 7000 \\
A8 & 5 & 5 & 5 & 9000 \\
A9 & 5 & 5 & 5 & 10000 \\
A10 & 3 & 4 & 3 & 8500 \\
A11 & 5 & 5 & 5 & 7000 \\
A12 & 3 & 3 & 3 & 6000 \\
A13 & 3 & 3 & 3 & 7500 \\
A14 & 3 & 5 & 3 & 8000 \\
A15 & 5 & 5 & 5 & 9500 \\
\hline
\end{tabular}

Tabel 5. Pembobotan dapat pula disebut sebagai pembentukan matriks $\mathrm{x}$, selanjutnya yaitu melakukan proses normalisasi untuk setiap kriteria.

Normalisasi kriteria kekuatan beras (C1):

$$
\begin{aligned}
& \mathrm{A} 1 \mathrm{X}_{1,1}=\frac{x_{11}}{\operatorname{Max} x}=\frac{5}{5}=1 \\
& \mathrm{~A} 15 \mathrm{X}_{15}, 1=\frac{x_{151}}{\operatorname{Max} x}=\frac{5}{5}=1
\end{aligned}
$$

Normalisasi kriteria tekstur (C2):

$$
\begin{aligned}
& \mathrm{A} 1 \mathrm{X}_{1,2}=\frac{x_{12}}{\operatorname{Max} x}=\frac{3}{5}=0,6 \\
& \mathrm{~A} 15 \mathrm{X}_{15,2}=\frac{x_{152}}{\operatorname{Max} x}=\frac{5}{5}=1
\end{aligned}
$$

Normalisasi kriteria aroma (C3):

$$
\begin{aligned}
& \mathrm{A} 1 \mathrm{X}_{1,3}=\frac{x_{13}}{\operatorname{Max} x}=\frac{5}{5}=1 \\
& \mathrm{~A} 15 \mathrm{X}_{15}, 3=\frac{x_{153}}{\operatorname{Max} x}=\frac{5}{5}=1
\end{aligned}
$$


Normalisasi kriteria harga (C4):

$$
\begin{aligned}
& \mathrm{A}_{1} \mathrm{X}_{1,4}=\frac{\operatorname{Min} x}{x_{14}}=\frac{6000}{8500}=0,7059 \\
& \mathrm{~A} 15 \mathrm{X}_{15}, 4=\frac{\operatorname{Min} x}{x_{154}}=\frac{6000}{9500}=0,6316
\end{aligned}
$$

Perhitungan di atas akan menghasilkan sebuah matriks ternormalisasi $r$, seperti pada Tabel 6 . Normalisasi.

\begin{tabular}{lllll}
\multicolumn{5}{c}{ Tabel 6. Normalisasi } \\
\hline Alternatif & C1 & C2 & C3 & C4 \\
\hline A1 & 1 & 0,6 & 1 & 0,7059 \\
A2 & 1 & 0,6 & 1 & 0,75 \\
A3 & 0,6 & 1 & 1 & 0,7059 \\
A4 & 1 & 0,8 & 0,6 & 0,75 \\
A5 & 0,6 & 1 & 1 & 0,7059 \\
A6 & 1 & 1 & 1 & 0,7059 \\
A7 & 1 & 0,8 & 0,6 & 0,8571 \\
A8 & 1 & 1 & 1 & 0,6667 \\
A9 & 1 & 1 & 1 & 0,6 \\
A10 & 0,6 & 0,8 & 0,6 & 0,7059 \\
A11 & 1 & 1 & 1 & 0,8 \\
A12 & 0,6 & 0,6 & 0,6 & 1 \\
A13 & 0,6 & 0,6 & 0,6 & 0,8 \\
A14 & 0,6 & 1 & 0,6 & 0,75 \\
A15 & 1 & 1 & 1 & 0,6316 \\
\hline
\end{tabular}

Langkah selanjutnya mengoptimalkan atribut dengan mengalikan terhadap bobot dari setiap kriteria. Proses perhitungan untuk mendapatkan yaitu sebagai berikut:

$$
\begin{aligned}
& \text { A1 } \\
& \mathrm{Q} 1=0,5 \sum(1 \times 5)+(0,6 \times 4)+(1 \times 3)+(0,7059 \\
& \text { x 2)+0,5 П }(1)^{5} *(0,6)^{4} *(1)^{3} *(0,7059)^{2} \\
& =5,9382 \\
& \cdots \\
& \cdots \\
& \cdots \\
& \cdots \\
& \mathrm{Q} 15=0,5 \sum(1 \times 5)+(0,6 \times 4)+(1 \times 3)+ \\
& (0,7059 \times 2)+0,5 \prod(1)^{5} *(0,6)^{4} *(1)^{3} * \\
& (0,7059)^{2} \\
& =5,9382
\end{aligned}
$$

\section{A15}

Hasil akhir atau nilai perangkingan dari perhitungan di atas secara lengkap dapat dilihat pada table 7.
Tabel 7. Perangkingan

\begin{tabular}{llcl}
\hline Alternatif & Keterangan & Hasil & Peringkat \\
\hline A11 & Beras Pelita & 7,12 & 1 \\
A6 & Metik Wangi & 6,9551 & 2 \\
A8 & Beras Merah & 6,8889 & 3 \\
A15 & Beras Emas & 6,8310 & 4 \\
A9 & Beras Hitam & 6,7799 & 5 \\
A2 & Ramos & 5,9865 & 6 \\
A1 & Pandan Wangi & 5,9382 & 7 \\
A7 & C4 & 5,8896 & 8 \\
A4 & IR42 & 5,7749 & 9 \\
A5 & Beras Lembang & 5,7253 & 10 \\
A3 & Rojo Lele & 5,7253 & 11 \\
A14 & Beras Jasmine & 5,1547 & 12 \\
A10 & Beureum Sengit & 4,7076 & 13 \\
A12 & Beras Bulog & 4,6011 & 14 \\
A13 & Beras Mutiara & 4,4007 & 15 \\
\hline
\end{tabular}

Berdasarkan Tabel 7. Perangkingan dapat diambil pernyataan bahwa beras terbaik yang tepat untuk digunakan sebagai bahan pembuatan kue serabi adalah beras pelita dengan hasil 7,12 dengan menduduki rangking pertama. Membuktikan hasil dari metode Weighted Aggregated Sum Product Assesment, maka dilakukan kuisioner secara langsung kepada pedagang kue serabi, khususnya yang ada di Tegal menghasilkan prosentase $80 \%$ dari 100, yang mengatakan bahwa beras pelita adalah beras yang layak untuk dijadikan sebagai bahan pembuatan kue serabi karena kue serabi yang dihasilkan lebih wangi dan segar dan harganya pun relatif murah.

\section{KESIMPULAN}

Setelah dilakukan penelitian dan implementasi metode Weighted Aggregated Sum Product Assessment (WASPAS) dalam penentuan beras terbaik yang kemudian akan dibuat sebagai bahan pembuatan kue serabi, maka peneliti menyimpulkan bahwa, hasil penelitian mengatakan bahwa beras pelita adalah beras yang terbaik yang layak digunakan dalam pembuatan kue serabi dengan nilai 7,12 dari beberapa pilihan alternatif beras yang ada. Membuktikan hasil dari metode WASPAS, maka dilakukan kuisioner secara langsung kepada pedagang kue serabi, khususnya yang ada di Tegal menghasilkan prosentase $80 \%$ dari 100, yang mengatakan bahwa beras pelita adalah beras yang layak untuk dijadikan sebagai bahan pembuatan kue serabi karena kue serabi yang dihasilkan lebih wangi dan segar dan harganya pun relatif murah.

\section{SARAN}

Adapun saran yang dapat peneliti sampaikan kepada pengembang selanjutnya adalah sebagai berikut:

a. Pada penelitian ini hanya menggunakan 4 data kriteria dan 15 alternatif beras yang ada. 
Pada pengembangan penelitian berikutnya data kriteria dan alternatif dapat ditambahkan lebih banyak lagi sesuai kebutuhan.

b. Dalam peningkatan pengembangan selanjutnya, harus dipahami secara benar kriteria yang sekiranya mempengaruhi nilai beras, karena itu adalah aspek utama dalam menentukan beras terbaik sehingga hasil yang didapat lebih maksimal.

\section{DAFTAR PUSTAKA}

AMALIA, V., SYAMSUAR, D. and ATIKA, L. 2019. Komparasi Metode WP SAW dan WASPAS Dalam Penentuan Penerima Beasiswa Penelusuran Minat dan Kemampuan. Jurnal Informatika, 6(1), pp. 114-121.

ANDINI, A. et al. 2018. Penerapan Sistem Pendukung Keputusan Pemilihan Ban Sepeda Motor Honda Dengan Metode Multi Objective Optimization on The Basic of Ratio Analysis ( MOORA ). JURIKOM (Jurnal Riset Komputer), 5(1), pp. 29-35.

BARUS, S. et al. 2018. Sistem Pendukung Keputusan Pengangkatan Guru Tetap Menerapkan Metode Weight Aggregated Sum Product Assesment ( WASPAS ). Media Informatika Budidarma, 2(2), pp. 10-15.

CHAKRABORTY, S. and ZAVADSKAS, E. K. 2014. Applications of WASPAS method in manufacturing decision making. Informatica (Netherlands), 25(1), pp. 1-20. doi: 10.15388/Informatica.2014.01.

CHANDRA, K. A. and HANSUN, S. 2019. Sistem Rekomendasi Pemilihan Laptop Dengan Metode Waspas. Jurnal Ecotipe (Electronic, Control, Telecommunication, Information, and Power Engineering), 6(2), pp. 76-81. doi: 10.33019/ecotipe.v6i2.1019.

GULO, H. 2020. Sistem Pendukung Keputusan Pemilihan Kantor Pos Terbaik Menerapkan Metode WASPAS. Journal of Information Sistem Research (JOSH), 1(2), pp. 81-86.

GUSMAN, A. P., LINOSTU, R. R. and SUMARYANTI. 2020. Implementasi metode waspas untuk menentukan ikan teri asin kering berkualitas terbaik. JOISIE Journal of Information System And Informatics Engineering, 4(1), pp. 36-42.

HANDAYANI, M. and MARPAUNG, N. 2018. Implementasi Metode Weight Aggregated Sum Product Assesment ( Waspas ) Dalam
Pemilihan Kepala Laboratorium. Seminar Nasional Royal (SENAR), 4(3), pp. 253-258.

ICKHSAN, M. et al. 2018. Sistem Pendukung Keputusan Pemberian Kredit Usaha Rakyat ( KUR ) Menggunakan Metode Weighted Product. JURIKOM (Jurnal Riset Komputer), 5(2), pp. 9-10.

MARBUN, E. D. et al. 2018. Penerapan Metode Weighted Aggregated Sum Product Assessment Dalam Menentukan Tepung Terbaik Untuk Memproduksi Bihun. Jurnal Riset Komputer (JURIKOM), 5(1), pp. 24-28.

NISA, K. 2020. Metode Moora Dan Waspas Untuk Pengambilan Keputusan Penentuan Prioritas Dalam Peningkatan Kualitas Mata Pelajaran. Jurnal Teknologi Informasi, 4(1).

STANUJKIĆ, D. and KARABAŠEVIĆ, D. 2019. An extension of the WASPAS method for decision-making problems with intuitionistic fuzzy numbers: a case of website evaluation. Operational Research in Engineering Sciences: Theory and Applications, 1(1), pp. 29-39. doi: 10.31181/oresta19012010129s.

TUNDO, T. and KURNIAWAN, D. 2019. Implementation of the Weighted Aggregated Sum Product Assesment Method in Determining the Best Rice for Serabi Cake Making. IJID (International Journal on Informatics for Development), 8(1), p. 40. doi: 10.14421/ijid.2019.08107.

TURSKIS, Z. et al. 2019. A fuzzy WASPAS-based approach to determine critical information infrastructures of EU sustainable development. Sustainability (Switzerland), 11(2). doi: 10.3390/su11020424. 